\title{
Rift that will Host Important Deposits of Hydrocarbons: A Review of the Petrologic Constraints Recorded by the Mantle Peridotites from Ophiolite Massifs
}

\author{
Kasturi Bhattacharyya* \\ Geology and Geophysics, Indian Institute of Technology, Kharagpur, India
}

\begin{abstract}
Rift formation has long been the focus of attention for researchers, and numerous studies have been carried out in order to understand causes and modes of whole lithospheric extension. The process of lithospheric rifting is classically considered to be a product of "active rifting" or "passive rifting", depending upon which forces are involved at the inception of rifting. Continental rifting is conventionally described as a thinning process of the whole lithosphere, ultimately leading to rupture of the continent, onset of sea-floor spreading and the consequent formation of a mid-oceanic ridge. Rifting is the initial and fundamental process by which the separation of a continent into two tectonic plates takes place. Active rifting or mantle-activated rifting has been classically ascribed to the ascent of a mantle plume impinging upon the base of the lithosphere, with consequent heating and thinning of the lithosphere. Passive rifting has been classically considered the result of horizontal stretching of the continental lithosphere, in which far-field tectonic stresses, generated at the boundaries of the lithospheric plates, result in lithosphere extension. Continental rifts are the sites of significant oil and gas accumulations, such as the Viking Graben and the Gulf of Suez Rift. Thirty percent of giant oil and gas fields are found within such a setting. In 1999 it was estimated that there were 200 billion barrels of recoverable oil reserves hosted in rifts.
\end{abstract}

Keywords: Rift; Hydrocarbons; Peridotites

\section{Introduction}

Piccardo et al. studied from time the passive continental rifting leading to opening of the fossil Jurassic Ligurian Tethys oceanic basin, by investigating the structural ad petrologic features recorded in the mantle peridotites of the Alpine-Apennine orogeny (NorthWest Italy), that represent the direct exposure in nature of the mantle lithosphere of the basin. Passive lithosphere extension is testified by $\mathrm{km}$-scale extensional shear zones, induced by far field tectonic forces, which thinned the sub-continental lithosphere and caused the passive upwelling of the asthenosphere (the passive a-magmatic rifting stage). After significant adiabatic upwelling, asthenosphere underwent decompression melting and the melts infiltrated through the extending lithospheric mantle by diffuse porous flow, frequently exploiting porosity bands of former shear zones (the passive magmatic rifting stage). Deformation and melt percolation interacted and mutually enhanced, strongly modifying the rheological characteristics of the mantle lithosphere along the axial zone of rifting (forming a weakened/ softened mantle wedge). The passive rifting system changed to splitting and continental break-up, passing to an active rifting system in the case deeper/hotter asthenosphere actively upwelled within the axial zone of weakened mantle lithosphere. Apennine orogeny (NorthWest Italy), that represent the direct exposure in nature of the mantle lithosphere of the basin. Passive lithosphere extension is testified by $\mathrm{km}$-scale extensional shear zones, induced by far field tectonic forces, which thinned the sub-continental lithosphere and caused the passive upwelling of the asthenosphere (the passive a-magmatic rifting stage). After significant adiabatic upwelling, asthenosphere underwent decompression melting and the melts infiltrated through the extending lithospheric mantle by diffuse porous flow, frequently exploiting porosity bands of former shear zones (the passive magmatic rifting stage). Deformation and melt percolation interacted and mutually enhanced, strongly modifying the rheological characteristics of the mantle lithosphere along the axial zone of rifting (forming a weakened/ softened mantle wedge). The passive rifting system changed to splitting and continental break-up, passing to an active rifting system in the case deeper/hotter asthenosphere actively upwelled within the axial zone of weakened mantle lithosphere. Both processes produce different rifted continental margins that is Active Rifting : bottom-up processes involving mantle upwelling/plumes (chemical thermal anomalies) drive active rifting and the formation of volcanic rifted (continental) margins and associated sub-aerial LIPs or flood basalt provinces (e.g., N Atlantic-Greenland and the Iceland plume; Southern Red Sea and the Afar plume). Davison et al. Geological evolution of the southeastern Red Sea Rift margin, Republic of Yemen White and McKenzie Magmatism at rift zones: The generation of volcanic continental margins and flood basalts.

\section{Passive rifting}

Top-down processes involving plate motions drive passive rifting and the formation of non-volcanic (continental) margins (e.g. IberiaNewfoundland margin) or within continents (e.g., Eastern China). Liguria is a classic on-land example of a Tethyan passive margin. PérezGussinyé et al. The rift to drift transition at non-volcanic margins: Insights from numerical modeling.

\section{Continuum}

In some regions there is a continuum between volcanic and non-

*Corresponding author: Kasturi Bhattacharyya, Indian Institute of Technology Kharagpur-721 302, India, Tel: +91-3222-255221; Fax: +91-3222-255303; E-mail: kasturi03.bhattacharyya@gmail.com

\section{Received April 29, 2015; Accepted June 10, 2015; Published June 17, 2015}

Citation: Bhattacharyya K (2015) Rift that will Host Important Deposits of Hydrocarbons: A Review of the Petrologic Constraints Recorded by the Mantle Peridotites from Ophiolite Massifs. Global J Technol Optim 6: 183. doi:10.4172/2229-8711.1000183

Copyright: (c) 2015 Bhattacharyya K. This is an open-access article distributed under the terms of the Creative Commons Attribution License, which permits unrestricted use, distribution, and reproduction in any medium, provided the original author and source are credited. 
volcanic margins and active and passive rifting. The southern Red Sea (Ethiopia-Yemen) margins resulted from active rifting (Afar plume) whereas the northern Red Sea-Gulf of Suez and the eastern Gulf of Aden margins resulted from passive rifting processes.

\section{Mantle Process}

The process of "melt thermal advection" means "heat advection by magma transport" [1] or "the effect of advection of heat by ascending melt" [2]. The process of thermal erosion (i.e., "tempera-ture increase in the lithosphere induced by the asthenosphere"), is used, for instance, by Viljoen [3] for the Merensky Reef in the western Bushveld Complex, by Müntener et al. [4], Piccardo [5], Bodinier et al. [6] and many others for alpine orogenic and ophiolitic peridotites, by Griffin et al. [7] Zhang et al. [8,9] and Menzies and Xu [10] for the North China Craton, and by O'Reilly and Griffin [11] for continental cratons. The process of Chemical erosion (i.e., "both chemical depletion and enrich-ment") is used, for instance, by Müntener et al. [4], Piccardo [4], Bodinier et al. [6] and many others for orogenic and ophiolitic peridotites, by Zhang et al. [8,9] and Kusky et al. [12] for the North China Craton, by Xu et al. [13] and Coltorti et al. [11] for CapoVerde, and by Rivalenti et al. [14] for Fernando de Noronha, Carlson [15]. The process of asthenospherization (i.e., "temperature increase in the mantle lithosphere up to asthenospheric values"), is used, for instance, by Bodinier and Godard [16], Piccardo [4], and Müntener et al.[17] for Lanzo, by Vauchez and Garrido [18] and Marchesi et al. [19] for Ronda, by Vauchez et al. [20] for Tanzania xenoliths, by Tommasi et al. [21] for Syberian xenoliths, and by Bascou et al. [22] for Kerguelen, Tang et al. [23] for NE China Craton. The process of Rejuvenation (i.e., "major, trace element and isotopic equilibration of older mantle litho-sphere with younger percolating melts", is used, among others, by Lenoir et al. [24] for Massif Central, by Houseman and Molnar [25] for orogens, by Li et al. [26] for the Hawaiian plume, by Beccaluva et al.[27] for the Hoggar swell, by Foley [28] for continental cratons, by Lister et al. [29] for collision and subduction, by Lorand et al. [30] for the Oman ophiolites, and by Guarnieri et al. [31] for the Lanzo peridotites). Foley [28], Griffin et al. [32], Roy et al. [33] and O’Reilly and Griffin [34] sustained that the sub-continental lithospheric mantle plays an important role in destabilizing continents and tectonic plates, by thermal and chemical modifications during infiltration of melts into the lithospheric mantle column. According to these authors, the meltinfiltration process represents the primary mechanism for weakening and rejuvenating the continental plate through thermal effects. Craton, and by O'Reilly and Griffin [35] for continental cratons. The process of Chemical erosion (i.e., "both chemical depletion and enrichment") is used, for instance, by Müntener et al., Piccardo Bodinier et al. and many others for orogenic and ophiolitic peridotites, by Zhang et al. $[8,23]$ and Kusky et al. for the North China Craton, by Xu et al. and Coltorti et al. for CapoVerde, and by Rivalenti et al. for Fernando de Noronha, Carlson [36]. The process of asthenospherization (i.e., "temperature increase in the mantle lithosphere up to asthenospheric values"), is used, for instance, by Bodinier and Godard, Piccardo and Müntener et al. for Lanzo, by Vauchez and Garrido and Marchesi et al. for Ronda, by Vauchez et al. for Tanzania xenoliths, by Tommasi et al. for Syberian xenoliths, and by Bascou et al. for Kerguelen, Tang et al. for NE China Craton. The process of Rejuvenation (i.e., "major, trace element and isotopic equilibration of older mantle litho-sphere with younger percolating melts", is used, among others, by Lenoir et al. for Massif Central, by Houseman and Molnar for orogens, by Li et al. for the Hawaiian plume, by Beccaluva et al. for the Hoggar swell, by Foley for conti-nental cratons, by Lister et al. for collision and subduction, by
Lorand et al. [37] for the Oman ophiolites, and by Guarnieri et al. for the Lanzo peridotites). Foley, Griffin et al., Roy et al. and O'Reilly and Griffin sustained that the sub-continental lithospheric mantle plays an important role in destabilizing continents and tectonic plates, by thermal and chemical modifications during infiltration of melts into the lithospheric mantle column. According to these authors, the meltinfiltration process represents the primary mechanism for weak-ening and rejuvenating the continental plate through thermal effects.

\section{Subsolidus Recrystallization, Partial Melting and Melt Percolation}

We frequently refer to the subsolidus (metamorphic) transition between spinelto plagioclase-peridotite facies conditions, to melt percolation and interaction under subsolidus conditions, when discussing mantle lithosphere exhumation and asthenospheric melt porous flow migration. In these cases, we do not refer to mantle partial melting at solidus or supra-solidus conditions. Available studies on subsolidusequilibrated plagioclase peridotites have documented that the spinelto plagioclase lherzolite subsolidus transition is a continuous reaction marked by progressive chemical changes in pyroxenes and spinel, in response to the crystallization of plagioclase. This is poorly supported by parallel experimental investigations, be-cause a few studies have been so far performed at subsolidus conditions and in complex chemical compositions approaching those of natural peridotites. Most of the experimental works have been performed at solidus conditions ( T N $1200^{\circ} \mathrm{C}$ ), because they addressed mantle partial melting and low-P mid-ocean ridge basalt (MORB) generation [28-45]. These studies indicate that the plagioclase-out boundary occurs at pressures between 1.0 and $1.5 \mathrm{GPa}$, and at solidus temperatures, in variably depleted perido-tites, suggesting a bulk composition dependence $[45,46]$. Concerning peridotite melting, when mantle peridotite reaches its solidus $\mathrm{P}-\mathrm{T}$ conditions, it undergoes partial melting and the composition of the formed melt is in equilibrium with the mineralogical assemblage of peridotite. As evidenced by Chalot-Prat et al. [47], long time experimental results give the composi-tions of melt in equilibrium with a mineralogical assemblage at given $\mathrm{P}-\mathrm{T}$ conditions. In the case of melt infiltration and porous flow percolation through the colder lithospheric mantle, the percolating melts derive from deeper and hotter asthenospheric levels. These melts are, accordingly, not in equilibrium with the percolated mantle lithosphere, and undergo melt/peridotite interaction during reactive porous flow percolation. In fact, mantle lithosphere is at temperature conditions lower than its solidus temperature and it does not undergo a partial melting process but, on the contrary, a melt/rock reaction process (i.e., melt and host peridotite assemblages are not in equilibrium). These processes are well documented by melt/peridotite reaction micro-textural features (clinopyroxene + olivine dissolution, orthopyroxene + plagioclase crystallization) and by compositional characteristics, as they are amply described and documented from decades in the international scientific bibliography. The previous papers [48-54] evidenced that mantle minerals of the melt-reacted peridotites always show compositional zoning of major and trace elements, suggesting that melt/mineral equilibration of the bulk system was never significantly developed. In rare cases, min-erals show poorly developed zoning and could be interpreted as indicating of approach to melt/mineral equilibration. As a whole, the rocks we studied cannot be considered to represent an equilibrated bulk compo-sition at a particular $\mathrm{P}$ and $\mathrm{T}$, that has no mineralogical memory of its origin, since the component minerals preserve clear major, trace and isotopic signatures that unravel their origin and some steps of their previous evolution. In our cases, 
infiltrated peridotites were heated by melt thermal advection up to $1300^{\circ} \mathrm{C}$ and some important trace elements were redistributed under equilibrium conditions at those thermal conditions. Further cooling stages did not affect their equilibrium distribution, since diffusion of these trace elements was prevented at lowered thermal conditions. In conclusion, I think that mineral/mineral or mineral/melt equili-bration cannot be simply and solely evaluated on the basis of the distri-bution of the most

common major elements, and that trace element and isotope distribution are important tools to unravel the origin and previous histories of minerals and rocks. Chalot-Prat et al. attempting to investigate the origin and re-lationships of processes of magmatism and lithosphere refertilization (i.e., formation of plagioclase peridotites), performed an experimental approach where they have determined the compositions of liquids and co-existing minerals in the six phase assemblage [liquid + olivine + orthopyroxene + clinopyroxene + plagioclase + spinel] at $0.5 \mathrm{GPa}$ and $1100^{\circ} \mathrm{C}$ to $1200^{\circ} \mathrm{C}$. They compared their experimental assem-blages, at $0.5,0.75$ and $1 \mathrm{GPa}$, with the compositions of minerals from plagioclase \pm spinel lherzolite at Lanzo. Field, petrological and geochemical studies evidenced that the Lanzo plagioclase peridotites are 'refertilized' (plagioclase + orthopyroxene crystallization, olivine + clinopyroxene dissolution) by the reaction of residual peridotite with percolating silica-saturated derivative basaltic magma. Accordingly, Chalot-Prat et al. applied the results of experimental equilibrium partial melting to natural melt/peridotite disequilibrium interaction and impregnation. Chalot-Prat et al. concluded that Lanzo plagioclase \pm spinel lherzolites equilibrated at pressures between 0.75 and $1 \mathrm{GPa}$, at temperatures $\sim 100-200^{\circ} \mathrm{C}$ below the solidus and their experimental study suggests that the process of refertilization took place at depths of $25-30 \mathrm{~km}$. In any case, these assertions confirm previous $\mathrm{P}-\mathrm{T}$ estimates for the formation of the South Lanzo plagioclase peridotites. It must be recalled, as summarized by Piccardo (in press, and references therein) on the basis of knowledge on the Ligurian Tethys plagioclase peridotites, that melt impregnation, via melt/rock reaction, causes interstitial crystallization of plagioclase and gabbro-norite micro-aggregates, that occurs at temperature conditions lower than solidus conditions of the host peridotite. Plagioclase and gabbro-noritic materials don't crystallize from melt formed by in situ partial melting of the host peridotite, but from exotic melts migrating from the asthenosphere, which infiltrate into and crystallize within the mantle lithosphere. Such liquids modified their composition by melt/peridotite interaction to attempt to reach equilib-rium with the host peridotite, during high melt/rock ratio and open system conditions, towards increasingly silica-saturated derivative liq-uids [55-57]. Plagioclase + orthopyroxene impregnation and gabbro-norite pods represent, accordingly, the crys-tallization product of the silica-saturated, strongly trace element deplet-ed basaltic melts. They attained silica-saturation during previous melt/ peridotite interaction under spinel-facies conditions and were not in chemical equilibrium with the host peridotite that they infiltrated by porous flow under shallower plagioclase-facies conditions. More simply, depending on physical and compositional characteris-tics of the system, plagioclase impregnation can occur within the whole plagioclase-facies stability field in mafic and ultramafic systems, when thermal conduction (i.e.,decreasing temperature) induces its crystallization in the pertinent system. Accordingly, plagioclase impregnation does not occur at melting conditions but, more realistic, at subsolidus conditions when melt begins interstitial crystallization of plagioclase and gabbro-norite micro-aggregates, due to prevailing thermal conduction (i.e., conductive cooling) on melt thermal advection (i.e., advective heating). Accordingly, plagioclase crystallization during impregnation is in equilibrium with a derivative melt, modified by melt/rock reaction, and certainly not in equilibrium with a melt formed by in-situ partial melting of the host peridotite. Subsolidus experiments by Borghini et al. [58], performed at pressures lower than $1.0 \mathrm{GPa}$ and temperatures ranging from 900 to $1200^{\circ} \mathrm{C}$, on fertile and depleted anhydrous lherzolites, show that a plagioclase-bearing assemblage is stable up to $0.7-0.8 \mathrm{GPa}$ (at $\mathrm{T}$ in the range $1000-1100^{\circ} \mathrm{C}$ ), whereas in the depleted lherzolite the upper limit of plagioclase stability is shifted to lower pressure.

Accordingly, for the sake of simplification, we consider the subsolidus (metamorphic) spinel-to plagioclase-facies transition in natural peridotites at $\mathrm{P}=$ or $\mathrm{b} 1.0 \mathrm{GPa}$, at the temperature condi-tions evaluated in the paper.

\section{The Lithosphere-Asthenosphere Boundary}

In our schematic and oversimplified figures we simply report the contact between lithosphere and asthenosphere without any interpretation of the boundary. As reported by Green et al. [59] the reason for differentiation at the lithosphere-as-thenosphere boundary (LAB) is currently being debated with relevant observations from geophysics (including seismology) and geochemistry (including experimental petrology). Water is thought to have an important effect on mantle rheology. Anderson [60] sustained that "Lithosphere is a mechanical concept implying strength and relative permanence. Unfortunately, the term has also been applied to the sur-face thermal boundary layer (TBL) and a shallow enriched geochemical reservoir, features having nothing to do with strength". As sustained by Fischer et al. [61] seismological models provide new constraints on the physical and chemical properties that differentiate the lithosphere from the asthenosphere. The oceanic lithosphere may correspond to a dry, chemically depleted layer over a hydrated, fertile asthenosphere. In this case, observed seismic velocity gradients at $\mathrm{LAB}$ require a contrast in mantle hydration, fer-tility, and/or melt content, perhaps in combination with a vertical gradient in velocity anisotropy. Beneath cratons, some studies con-clude that the cratonic lithosphere-asthenosphere boundary is grad-ual enough to be matched by a purely thermal gradient, whereas others indicate a more rapid transition and a contrast in composition or perhaps melt content. Panza et al. [62] and Doglioni et al. [63] outlined the existence of viscosity contrast and decoupling between lithosphere and asthenosphere, and suggested that theboundary is a shear zone. Since the discussion of the nature of LAB is out of the scope of our work, we leave the $\mathrm{LAB}$ in our figures without any interpretation.

The lithosphere-asthenosphere system in Italy and surroundings has been thoroughly discussed by Panza et al. [64] and Tuamanian et al. Concerning the reference depth of LAB preceding onset of pas-sive extension, the recent work of Brandmayr et al. [65], "obtained picture of the lithosphere-asthenosphere system for the Italic region which confirms a mantle extremely vertically stratified and laterally strongly heterogeneous. The lateral variability in the mantle is interpreted in terms of subduction zones, slab dehydration, inherited mantle chemical anisotropies, asthenospheric upwellings, and so on", i.e., the recent of actual geodynamic processes acting in the region. In the figures, we use an arbitrary, maximum reference depth of $130 \mathrm{~km}$, taking into account that our data suggest that the lower lith-osphere should have been under garnet-peridotite facies conditions (P N 2.5-3.0 GPa).

Magmatic extension - melt porous flow infiltration through 


\section{the lithosphere}

Ongoing field, structural and petrologic studies reveal the presence, within the lherzolite shear zones of the Erro-Tobbio (Voltri Massif) peridotites, of decimetric-metric parallel bands which show peculiar structural and compositional features, with respect to the host lherzolite shear zone. In fact, they show recrystallized granular textures, which replace almost completely the strongly deformed structures of the previous shear zone, reactive micro-structures (pyroxene dissolvingolivine precipi-tating), strong pyroxenes depletion and harzburgite composition.

As discussed by Piccardo (in press), the structural, micro-textural and compositional features of these harzburgite bands, similar to the $\mathrm{km}$-scale bodies of pyroxene-depleted spinel harzburgites of the ErroTobbio Unit, are interpreted as records of melt/peridotite inter-action processes during diffuse reactive porous flow percolation [66].

Accordingly, the reactive harzburgite bands within the shear zones indicate that, after onset of asthenosphere partial melting, asthenospheric melts infiltrated along the pre-existing extensional shear zones and percolated by focused and reactive porous flow.

Recently, Mohajeri et al. [67] reported that, while the porosity observed in their simulations is probably not high enough to develop the magmatic dominated final stages of rifting and continental breakup, it would further aid in weakening the lithosphere and promoting localiza-tion of deformation and melt flow. Recent conceptual models based on experiments and field observations allow to explain the schematic rifting stages outlined above $[68,69]$. These processes could in turn enhance continental thinning and melt supply along the rift axis and eventually [70] could result in continental breakup and the forma-tion of a spreading center (where extension is predominantly accom-modated by magma accretion).

Mohajeri et al. stated that this outcome provides insights into the formation of melt features and shear structures observed in extensional regimes.

Accordingly, the structural and rheological features of the patterned and structured lower lithosphere (i.e. the presence of melt-free porosity bands and shear zones) of the Ligurian peridotites allowed and enhanced melt infiltration via diffuse and focused, reactive porous flow through the host peridotite and melt uprising to shallower levels. Melt saturation and crystallization under plagioclase-peridotite facies conditions. Melt stagnation and storage in the shallow lithosphere evidenced that liquids rising adiabatically from the asthenosphere dissolve pyroxenes and crystallize olivine, that is induced by rapid reaction and slow cooling, during which liquid mass increases. According to Kelemen et al., the melt/peridotite reaction process during upwards melt porous flow mi-gration gradually depletes in pyroxenes the percolated peridotites forming reactive spinel harzburgites, whereas the percolating melts attained silica(- orthopyroxene)-saturation, and were transformed into silica(- orthopyroxene)-saturated derivative liquids, formed by melt-peridotite reaction.

Structural and petrologic investigations on the Ligurian ophiolitic pe-ridotites indicate that these silica (-orthopyroxene)-saturated, deriva-tive liquids, when migrated to relatively shallow mantle levels (i.e., plagioclase-peridotite facies conditions), reacted with the host perido-tites, dissolving olivine and crystallizing orthopyroxene + plagioclase. When they reached their liquidus temperature under plagioclase-peridotite facies conditions, they caused extensive impregnation and refertilization of the shallow lithospheric mantle.
These derivative melts pre-served the strongly depleted geochemical signature of their primary melts (i.e., strong trace element depletion attained by low degrees of fractional melting of a DM spinel-facies mantle source).

Mantle peridotites, that were exhumed and exposed at the seafloor at more distal settings during Jurassic continental breakup in the Liguri-an Tethys domain, consist of plagioclase-bearing/enriched peridotites. The presence of hot melt-impregnated shallow lithosphere indicates the relevance of processes of melt thermal advection that progressively modified the geothermal gradient towards a ridge-type geotherm. Time constraints to mantle evolution from continental rifting to oceanic spreading.

The tectonic and magmatic records evidence the mantle processes that were active in the lithosphere-asthenosphere system during passive extension of the lithosphere to oceanic sea-floor spreading:

- The passive a-magmatic rifting;

\section{The onset of asthenosphere partial melting;}

The melt reactive percolation and impregnation of the mantle lithosphere;

- The formation of a softened/weakened axial zone between the future continental margins;

- The active asthenosphere upwelling inside the wedge;

- The upwelling, intrusion and sea-floor extrusion of MORB melts;

- The establishment of a ridge-type system.

The timing of the tectonic and magmatic processes recorded in the Ligurian Tethys, from rifting onset to oceanic spreading, is based on reliable geochronological informations: (1) Sm/Nd, Lu/Hf and $\mathrm{Ar} / \mathrm{Ar}$ isochron ages and Os isotopes and $\mathrm{Sm} / \mathrm{Nd}$ model ages of spinel peridotites from the Ligurian Tethys ophiolites; (2) U-Pb SHRIMP, Ar/Ar and $\mathrm{Sm} / \mathrm{Nd}$ ages of intrusive rocks from western Alps, Apennines and Corsi-ca; and (3) biochronology of supra-ophiolitic radiolarites in the Alps and Apennines.

Rift-related processes in the marginal sub-continental peridotites. At North Lanzo some peridotites show alkaline OIB (Ocean Island Basalt) signatures and, in the $176 \mathrm{Hf} / 177 \mathrm{Hf}$ vs $176 \mathrm{Lu} / 177 \mathrm{Hf}$ diagram, are aligned along an errorchron with a slope corresponding to an age of 259 ( \pm 25$) \mathrm{Ma}$. This $\sim 260 \mathrm{Ma}$ errorchron was interpreted as the record of interaction and rejuvenation of the North Lanzo mantle by relatively young alkaline melts that percolated the mantle lithosphere before or during the onset of passive extension and exhumation. If this is the case, the early for-mation and percolation through the mantle lithosphere of alkaline melts could indicate that the onset of lithosphere extension occurred during Middle-Upper Permian.

Shear zones within (ex-garnet-)pyroxenites from the External Ligurides yielded $\mathrm{Lu}-\mathrm{Hf}$ isochrons which indi-cate a minimum age of $220+/-13 \mathrm{Ma}$ for subsolidus transition to plagioclase-facies assemblages. Amphibole-bearing shear zones from the Malenco peridotites [71-73] yielded 40Ar/39Ar ages (225 Ma) on amphiboles. These data indicate Upper Triassic subsolidus, melt-absent mantle processes during ongoing extension and exhumation of the mantle lithosphere and suggest that a significant exhumation of the lithospheric mantle has been already active during Upper Triassic, driving lower mantle lithosphere to shallower levels. Accordingly, these Upper 
Triassic ages cannot indicate onset of passive rifting but may represent intermediate steps of the a-magmatic passive rift evolution, which should have been started significantly earlier, during Triassic (or even during transition from Permian to Triassic).

The first appearance of melts. Some olivine gabbro bodies intruded into the Ligurian peridotites of the future Adria margin (External Liguride and Tuscany: Tribuzio et al. [74]; Erro-Tobbio, Voltri Massif: Borghini et al., [75] ), yielded Sm-Nd plg-cpx plg-wr-cpx isochrons in the range $170 \pm 13-180 \pm 14 \mathrm{Ma}$. They represent an earlier group of Lower-Middle Jurassic MORB-type olivine gabbros intruded during Early Jurassic ages into the future Adria subcontinental mantle lithosphere.

Melt reactive percolation and impregnation (stagnation) (hidden, non reactive magmatism). Time constraints from plagioclase peridotites and gabbro-norite dykelet. $\mathrm{Sm} / \mathrm{Nd} \mathrm{DM}$ model ages of clinopyroxenes from reactive depleted spinel peridotites yielded: (1) 170-175 Ma in the marginal Erro-Tobbio Massif (Ligurian Alps) [76] and (2) $165 \mathrm{Ma}$ in the marginal Monte Nero Massif (External Ligurides) [77,78]. Sm/Nd isochron ages from plagioclase-enriched lherzolites and gabbro-norite veins yielded Late Jurassic ages $(155 \pm 6 \mathrm{Ma})$ in the Mt. Maggiore (Corsica) distal peridotites [79].

These few data seem to indicate that melt percolation through the mantle lithosphere, related to asthenosphere partial melting, covers a broad range $175 \mathrm{Ma}-155 \mathrm{Ma}$ (from Middle to Upper Jurassic), which apparently is relatively older in the marginal subcontinental peridotites and younger in the distal oceanic peridotites.

Melt intrusion (MORB oceanic, eruptive magmatism). Middle Jurassic ages $(164 \mathrm{Ma})$ are provided by $\mathrm{Sm}-\mathrm{Nd}$ plg-wr-cpx isochrons from Internal Ligurides gabbroic intrusions [80,81]. Middle-Upper Jurassic Sm-Nd isochron ages are recorded by one gabbroic dyke (162 +/- $10 \mathrm{Ma}$ ) from Mt. Maggiore, Corsica [82]. Sm-Nd and U-Pb zircon results by Costa and Caby and Chalot-Prat et al. implied a multi-stage magmatic process over 30-50 m.y. Kaczmarek et al. [83] summa-rized published radiometric ages that indicate that MORB magmatism in the Piedmont-Ligurian ophiolites started in Middle Jurassic and lasted from about 170 to $155 \mathrm{Ma}$ (Upper Jurassic). Li et al. [84] based on the compilation of the reliable literature $\mathrm{U}-\mathrm{Pb}$ age data, reported that the ophiolitic gabbros from Eastern, Central and, Western Alps, Liguria and Corsica crystallized nearly synchronously at 166-158 Ma, indicating a short life span of b $11 \mathrm{~m}$.y. for the formation of the Piemont-Liguria oceanic domain. Although $\mathrm{Sm}-\mathrm{Nd}$ isochron ages appear now-a-day less precise than $\mathrm{U}-\mathrm{Pb}$ zircon ages, intrusion of aggregated MORBs, and their differentiates, within the shallow lithospheric mantle, can be considered to occur during Middle to Upper Jurassic.

Ocean opening and MORB extrusion. Bill et al. [85] revised the biochronology of supra-ophiolitic radiolarites in the Alps and Apennines and provided information on the onset of oceanic spreading in the Alpine Tethys and of oceanic MORB extrusion, since basaltic lava flows are frequently interbedded with the radiolarites. They suggested that biochronologic and isotopic ages currently indicate that oceanic spread-ing of the Alpine Tethys began during the Bajocian (Middle Jurassic) and continued until the Kimmeridgian (Upper Jurassic).

Accordingly, it can be extrapolated that onset of oceanization of the Ligurian Tethys basin and MORB eruption occurred during Middle to Upper Jurassic.

The presence/abundance of plagioclase peridotites in modern slow- ultraslow spreading oceans Von der Handt et al. [86] showed the increasing importance of re-active melt stagnation at upper mantle and lower crustal conditions with decreasing spreading rates, at slow-to ultraslow spreading ridges. They sustained the importance of melt-rock interaction at decreasing melt mass between refractory upper mantle rocks and primitive or evolved melts.

Processes of melt/peridotite interaction in abyssal peridotites, lead-ing to formation of plagioclase peridotites, have been recognized and described since a long time samples from modern slow-ultraslow spreading oceans. Plagioclase peridotites, related to melt percolation and impregnation, have been found in MAR, Gakkel Ridge and SWIR [87-98]. Dick discussed the presence and local abundance of plagioclase peridotites at SW Indian and America-Antarctic ultra-slow spreading ridges and put in relation the locally-abundant plagio-clase peridotites, where the plagioclase crystallized from impregnated trapped melt (up to $30 \%$ ), with non-uniform melt flow uprising beneath ocean ridges. According to von der Handt et al., few studies have been devoted to abyssal plagioclase peridotites, despite their relatively high abundance (30\% of abyssal peridotites), probably because intense alter-ation obliterates textural relationships and limits the spatial control of the geochemical studies. Although widespread alteration makes it diffi-cult to recognize structural and chemical records of these processes, percolation and crystallization of highly depleted melts in mantle sequences from slow-ultraslow spreading settings have been recognized on the basis of the compositions of clinopyroxenes from peridotites and websterite layers.

Plagioclase peridotite samples were dredged at the Romanche Fracture Zone of MAR. They are particularly rich in plagioclase (from 0.5 to 16.4 vol.\%) which is completely altered. Since majority of clinopyroxenes are depleted in strongly incompat-ible elements (i.e., $\mathrm{Sr}$ in the range $0.24-7.4 \mathrm{ppm}, \mathrm{Zr}$ in the range 0.42-33.0 ppm), trace element equilibration during plagioclase impregnation from strongly trace element depleted melts could be envisaged.

Dick et al. investigated the Kane Megamullion, an oceanic core complex near the Mid-Atlantic Ridge (MAR) close to the Kane Transform. They found large variations in peridotite composition for a single dredge, reflecting local melt transport through the shallow mantle.

They sustained that this process produced variable extents of meltrock reaction, dunite formation, and melt impregnation. More-over they found records of cryptic metasomatism by small volumes of late transient silica-rich melts infiltrating through the shallow mantle.

Direct evidence for such melts is seen in orthopyroxenite veins. Dick et al. report that plagioclase peridotites are generally abundant in transform fault zones and at a few localities, such as the Romanche FZ, contain large volumes of plagioclase (2-18 vol.\%).

Paganelli et al. described spinel and plagioclase peridotites dredged in the Southern Ridge Transform Intersection (RTI) (SWIR) of the Andrew Bain Fracture Zone (ABFZ). The overall textures of these samples account for important melt percolation/stagnation events occurred in the plagioclase and spinel field. They discussed the causes of inhibition of melt segregation during melt/rock interaction and melt ac-cumulation at depth, i.e. the formation of short scale permeability bar-riers beneath ABFZ or, alternatively, an anomalously thick conductive layer.

Peridotite samples were dredged at the eastern SWIR, between the Melville fracture zone and $63^{\circ} 67^{\prime} \mathrm{E}$, smooth seafloor and constitutes about $50 \%$ of the mapped area. The collected sam-ples are dominated 
by spinel peridotites but plagioclase-bearing perido-tites represent about $30 \%$ of the mantle derived samples in dredges Dr21 and Dr23 and the near totality of those of Dr14. Seyler et al. selected 24 samples of spinel peridotites, devoid of magmatic veins, lacking plagioclase or its alteration products and containing low- Ti spinels $\left(\mathrm{TiO}_{2}\right.$ b $\left.0.2 \%\right)$, to investigate local to regional trace element heterogeneities, and gain some insight into the length scale of the melting heterogeneities and as-sess the respective effects of melting-induced and source inherited heterogeneities.

Snow et al. presented new observations on Lena Trough in the Arctic Ocean that bear on the early phase of oceanic spreading in such rifts. They described that, at the center of Lena Trough, where no basalt is present, a greater proportion of veined and plagioclase-bearing peridotites occur, which are considered records of melt impreg-nation features related to non-eruptive, syn-rift magmatism. Litho-spheric entrapment of melts has thus been more efficient in the center of Lena Trough, producing thick lithosphere and thin (or non-existent) eruptive crust.

In the following, we concentrate on oceanic plagioclase peridotites (and a gabbro-norite body) which have unaltered clinopyroxene and plagioclase, showing major and trace element equilibration, to unravel some compositional characteristics of the percolated parental melts.

Unaltered plagioclase and pyroxenes have been found in some plagioclase peridotite samples dredged at Gakkel Ridge which show strongly depleted min-eral compositions. Clinopyroxenes show $\mathrm{Mg} \#$ in the range 90.2-92.3, Sr contents in the range 0.65-5.86 ppm and $\mathrm{Zr}$ contents in the range 2.40-18.10 ppm; plagioclases show An contents in the range 79.0-86.7 and $\mathrm{Sr}$ contents range $2.40-20.30 \mathrm{ppm}$ (two analyses with Sr contents of $155.6 \mathrm{ppm}$ and $65.1 \mathrm{ppm}$ are not considered). von der Handt et al suggested an impregnation origin for most of the plagioclase by an already fractionat-ed and depleted melt. The inferred composition of this melt cannot be correlated with the nearest basalts in this region or with a melt produced by melting of the spinel lherzolite.

The empirical thermometers of Seitz et al. [99] have been applied to the Gakkel Ridge plagioclase peridotites. They furnish very high TSc (T $1224-1237^{\circ} \mathrm{C}$ ), which suggests important melt thermal advec-tion processes to shallow lithospheric mantle levels at the Gakkel ultra-slow spreading ridge.

Few unaltered plagioclases have been found in peridotite samples drilled in the Atlantis II Fracture Zone on the Southwest Indian Ridge. Clinopyroxene rims showing Eu anomaly (i.e., trace element equilibrated with plagioclase) have low $\mathrm{Na}_{2} \mathrm{O}$ con-tents (in the range 0.18-0.39 wt.\%), low Sr contents (in the range 0.80-6.17 ppm) and low $\mathrm{Zr}$ contents (in the range 1.61-2.88 ppm), $\mathrm{Mg} \#$ ranges between 90.8 and 92.2. Plagioclases are highly anorthitic (An in the range 83.693.2) and have low $\mathrm{Sr}$ (in the range 1.4-57.8 ppm) and low $\mathrm{Zr}$ (in the range $0.12-0.46 \mathrm{ppm}$ ) contents, relatively to plagioclase in equi-librium with aggregated MORB. The strongly trace element depleted minerals compositions suggest a strongly depleted composition of the parental melt.

Peculiar mafic-ultramafic gabbro-norite cumulates, composed by plagioclase lherzolites, olivine gabbro-norites, gabbro-norites and noritic anorthosites, were sampled at DSDP Site 334 on the Mid Atlantic Ridge [100,101]. They contain olivine (Fo 85-90), high$\mathrm{Ca}$ and low-Ca pyroxenes (Mg\# 70-91) and plagioclase (An 75-90) and orthopyroxene is an abundant cumulus phase. Plagioclase has anomalously high anorthite content and pyrox-enes have very high $\mathrm{Mg} \#$ and $\mathrm{Cr}$ abundances, coupled with low $\mathrm{Na}$ and $\mathrm{Ti}$ in high-Ca pyroxenes and very low incompatible trace element abundances in pyroxenes. Abundance and early crystallization of magnesian orthopyroxene suggest that parental magmas of Site $334 \mathrm{cu}$-mulates were high silica (52-55 wt.\%) liquids. According to Ross and Elthon, the mineral compositions from these oceanic cumulates indicate that the rocks crystallized from basaltic liquids that were strongly depleted in $\mathrm{Na}, \mathrm{Ti}$, $\mathrm{Zr}, \mathrm{Y}, \mathrm{Sr}$ and Rare Earth Elements relative to any erupted MORB, that have been collected at crustal levels and remained sufficiently isolated to form distinctive cumulates. Ross and Elthon showed that fractional melting of the upwelling sub-oceanic mantle produces magmas with a much wider range of compo-sitions than erupted MORBs and it seems that strongly depleted primary magmas are routinely produced by melting beneath ridges [102]. These authors noted the absence of similar strongly depleted melts as erupted lavas.

\section{Conclusions}

This paper presents an updated review of the field, structural and petrologic constraints recorded by the mantle peridotites from ophiolite massifs that were induced by passive rifting leading to seafloor spreading.

Continental extension induced by passive rifting in the pre-Triassic Europe-Adria domain, caused lithosphere stretching and thinning by melt-free extensional shear zones and consequent almost adiabatic passive upwelling of the shallow asthenosphere (a-magmatic passive rifting). When lithosphere was thinned to half of his thickness, the passively upwelling asthenosphere reached its melting conditions on decompression under spinel-peridotite facies conditions. Reservoir rocks may be developed in pre-rift, syn-rift and post-rift sequences. Effective regional seals may be present within the post-rift sequence if mudstones or evaporites are deposited. Just over half of estimated oil reserves are found associated with rifts containing marine syn-rift and post-rift sequences, just under a quarter in rifts with a non-marine synrift and post-rift, and an eighth in non-marine syn-rift with a marine post-rift. Source rocks are often developed within the sediments filling the active rift (syn-rift), forming either in a lacustrine environment or in a restricted marine environment, although not all rifts contain such sequences.

\section{Acknowledgement}

I thank IIT Kharagpur support me with a fellowship to write the review paper.

\section{References}

1. Feigenson MD, Spera FJ (1980) Melt production by viscous dissipation: role of heat advection by magma transport. Geophys. Res Lett 7: 145-148.

2. Asimow PD (2002) Steady-state mantle-melt interactions in one dimension: II. Thermal interactions and irreversible terms. J Petrol 43: 1707-1724.

3. Viljoen MJ (1999) The nature and origin of the Merensky Reef of the western Bushveld Complex based on geological facies and geological data. S Afr J Geol 102: 221-239.

4. Piccardo O, Piccardo GB, Pettke T, Zanetti A (2003) Thermochemical erosion of mantle lithosphere by melt/rock reaction in the Lanzo peridotites (Italy) and implications for the transition from rifting to ultra-slow seafloor spreading American Geophysical Union.

5. Müntener O, Piccardo GB (2003) Melt migration in ophiolites: the message from Alpine- Apennine peridotites and implications for embryonic ocean basins. Geol Soc Lond Spec Publ 218: 69-89.

6. Bodinier JL (2005) Partial melting in Ronda versus refertilization in Lherz: two contrasting effects of lithospheric thermal erosion documented in orogenic peridotites. An International Journal on Ophiolites and Modern Oceanic Lithosphere 3. 
Citation: Bhattacharyya K (2015) Rift that will Host Important Deposits of Hydrocarbons: A Review of the Petrologic Constraints Recorded by the Mantle Peridotites from Ophiolite Massifs. Global J Technol Optim 6: 183. doi:10.4172/2229-8711.1000183

7. Griffin WL, Andi Z, O'Reilly SY, Ryan CG (1998) Phanerozoic evolution of the lithosphere beneath the Sino-Korean Craton. Mantle Dynamics and Plate Interactions in East Asia. American Geophysical Union, Washington DC.

8. Zhang HF, Sun M, Zhou XH, Zhou MF, Fan WM, et al. (2003) Secular evolution of the lithosphere beneath the eastern North China Craton evidence from Mesozoic basalts and high-Mg andesites. Geochimica et Cosmochim Acta 67 4373-4387.

9. Zhang HF, Ying JF, Santosh M, Zhao GC (2012) Episodic growth of Precambrian lower crust beneath the North China Craton: a synthesis. Precambrian Res 222-223: 255-264.

10. Menzies MA, Xu Y (2013) Geodynamics of the North China Craton. Mantle Dynamics and Plate Interactions in East Asia. American Geophysical Union, Washington, D.C.

11. Coltorti M, Bonadiman C, O'Reilly SY, Griffin WL, Pearson NJ (2010) Buoyan ancient continental mantle embedded in oceanic lithosphere (Sal Island, Cape Verde Archipelago). Lithos 120: 223-233.

12. Kusky TM, Windley BF, Zhai MG (2007) Tectonic evolution of the North China Block: from orogen to craton to orogen. Geol Soc Lond Spec Publ 280: 1-34.

13. Xu X, O'Reilly SY, Griffin WL, Zhou X( 2003) Enrichment of upper mantle peridotite: petrological, trace element and isotopic evidence in xenoliths from SE China. Chem Geol 198: 163-188.

14. Rivalenti G, Zanetti A, Girardi VAV, Mazzucchelli M, Tassinari CCG, et al (2007) The effect of the Fernando de Noronha plume on the mantle lithosphere in north-eastern Brazil. Lithos 94: 111-131.

15. Carlson RW (2005) Treatise on Geochemistry second edition. Geochemistry of the Mantle and Core Elsevier, Amsterdam 103-170.

16. Bodinier JL, Godar M (2003) Orogenic, ophiolitic, and abyssal peridotites. Elsevier 103-170.

17. Müntener O, Piccardo GB, Polino R, Zanetti A (2005) Revisiting the Lanzo perido- tite (NW-Italy): 'asthenospherization' of ancient mantle lithosphere. Ofioliti 30: 111-124.

18. Vauchez A, Garrido CJ (2001) Seismic properties of an asthenospherized lithospheric mantle: constraints from lattice preferred orientations in peridotite from the Ronda massif. Earth Planet. Sci Lett 192: 235-249.

19. Marchesi C (2010) Persistence of mantle lithospheric Re-Os signature during asthenospherization of the subcontinental lithospheric mantle: insights from in situ isotopic analysis of sulfides from the Ronda peridotite (Southern Spain). Contrib Mineral Petrol 159: 315-330.

20. Vauchez A, Dineur F, Rudnick R (2005) Microstructure, texture and seismic anisotropy of the lithospheric mantle above a mantle plume: insights from the Labait volcano xenoliths (Tanzania). Earth Planet Sci Lett 232: 295-314.

21. Tommasi A, Vauchez A, lonov DA (2008) Deformation, static recrystallization, and reactive melt transport in shallow subcontinental mantle xenoliths (Tok Cenozoic volcanic field, SE Siberia). Earth Planet Sci Lett 272: 65-77.

22. Bascou J (2008) An integrated study of microstructural, geochemical, and seismic properties of the lithospheric mantle above the Kerguelen plume (Indian Ocean). Geochem Geophys Geosyst 9.

23. Tang YJ, Zhang HF, Ying JF, Su BX, Chu ZY, et al. (2013) Highly heterogeneous lithospheric mantle beneath the Central Zone of the North China Craton evolved from Archean mantle through diverse melt refertilization. Gondwana Res 23: 130-140.

24. Lenoir X, Garrido CJ, Bodinier JL, Dautria JM (2000) Contrasting lithospheric mantle domains beneath the Massif Central (France) revealed by geochemistry of peridotite xenoliths. Earth Planet Sci Lett 181: 359-375.

25. Houseman G, Molnar P (2001) Mechanisms of lithospheric rejuvenation associated with continental orogeny. Geol Soc Lond Spec Publ 184: 13-38.

26. Li X1, Kind R, Yuan X, Wölbern I, Hanka W (2004) Rejuvenation of the lithosphere by the Hawaiian plume. See comment in PubMed Commons below Nature 427: 827-829.

27. Beccaluva L (2007) Intracratonic asthenosphere upwelling and lithosphere rejuve- nation beneath the Hoggar swell (Algeria): evidence from HIMU metasomatised Iherzolite mantle xenoliths. Earth Planet Sci Letters 260: 482-494.

28. Foley SF (2008) Rejuvenation and erosion of the cratonic lithosphere. Nat Geosci 1: 503-510.
29. Lister G, Kennett B, Richards S, Forster M (2008) Boudinage of a stretching slablet implicated in earthquakes beneath the Hindu Kush. Nat Geosci 1: 196201

30. Seyler M, Toplis MJ, Lorand JP, Luguet A, et al. (2001) Clinopyroxene microtextures reveal incompletely extracted melts in abyssal peridotites. Geology 29: 155-158.

31. Guarnieri L, Nakamura E, Piccardo GB, Sagaguchi C, Shimizu N, et al. (2012) Petrology, trace element and $\mathrm{SR}, \mathrm{Nd}$, $\mathrm{Hf}$ isotope geochemistry of the North Lanzo peridotite massif (Western Alps, Italy). J Petrol 53: 2259-2306.

32. Griffin WL, O'Reilly SY, Afonso JC, Begg GC (2009) The composition and evolution of lithospheric mantle: a re-evaluation and its tectonic implications. J Petrol 50: 1185-1204

33. Roy M, Orozco RO, Holtzman B, Gaherty J (2012) Melt-enhanced Rejuvenation of Lithospheric Mantle: Insights from the Colorado Plateau. Extensional processes in continental lithosphere. J Geophys Res 100: 24187-24215.

34. O'Reilly SY, Griffin WL (2013) Metasomatism and the chemical transformation of rock. Lect Notes Earth Syst Sci 471-533.

35. OReilly SY, Griffin WL (2010) The continental lithosphere-asthenosphere boundary: can we sample it? Lithos 120: 1-13.

36. Carlson RW (2005) Application of the Pt-Re-Os isotopic systems to mantle geochemistry and geochronology. Lithos 82: 249-272.

37. Lorand JP, Alard O, Godard M (2009) Platinum-group element signature of the primitive mantle rejuvenated by melt-rock reactions: evidence from Sumail peridotites (Oman Ophiolite). Terra Nova 21: 35-40.

38. Jaques AL, Green DH (1980) Anhydrous melting of peridotite at $0-15 \mathrm{~kb}$ pressure and the genesis of tholeiitic basalts. Contrib Mineral Petrol 73: 287310.

39. Takahashi E (1986) Melting of a dry peridotite KLB-1 up to $14 \mathrm{GPa}$ : implications on the origin of peridotitic upper mantle. J Geophys Res Solid Earth 91: 9367 9382

40. Falloon TJ, Green DH (1987) Anhydrous partial melting of MORB pyrolite and other peridotite compositions at $10 \mathrm{kbar}$ : implications for the origin of primitive MORB glasses. Mineral Petrol 37: 181-219.

41. Falloon TJ, Green DH (1988) Anhydrous partial melting of peridotite from 8 to $35 \mathrm{~kb}$ and the petrogenesis of MORB. J Petrol 1: 379-414.

42. Baker MB, Solper EM (1994) Determining the composition of high-pressure mantle melts using diamond aggregates. Geochim. Cosmochim. Acta 58 2811-2827.

43. Falloon TJ, Green DH, O'Neill HStC, Hibberson WO (1997) Experimental tests of low degree peridotite partial melt compositions: implications for the nature of anhydrous near-solidus peridotite melts at $1 \mathrm{GPa}$. Earth Planet Sci Lett 152 149-162.

44. Falloon TJ, Green DH, Danyushevsky LV, Faul UH (1999) Peridotite melting at 1.0 and $1.5 \mathrm{GPa}$ : an experimental evaluation of techniques using diamond aggregates and mineral mixes for determination of near-solidus melts. J Petrol 40: $1343-1375$.

45. Falloon TJ, Green DH, Danyushevsky LV, McNeill AW (2008) The composition of near-solidus partial melts of fertile peridotite at 1 and $1.5 \mathrm{GPa}$ : implications for the petrogenesis of MORB. J Petrol 49: 591-613.

46. Green DH, Falloon TJ (1998) Pyrolite: a ringwood concept and its current expression. The Earth's Mantle: Composition, Structure and Evolution. Cambridge University Press, Cambridge, UK.

47. Chalot-Prat F, Falloon TJ, Green DH, Hibberson WO (2013) Melting of plagioclase + spinel Iherzolite at low pressures $(0.5 \mathrm{GPa})$ : an experimental approach to the evolution of basaltic melt during mantle refertilisation at shallow depths. Lithos 172-173: 61-80.

48. Piccardo GB, Vissers RLM (2007) The pre-oceanic evolution of the Erro-Tobbio peridotite (Voltri Massif-Ligurian Alps, Italy). J Geodyn 43: 417-449.

49. Piccardo GB, Zanetti A, Müntener O (2007) Melt/peridotite interaction in the Lanzo South peridotite: field, textural and geochemical evidence. Lithos 94 : 181-209.

50. Piccardo GB, Zanetti A, Pruzzo A, Padovano M (2007) The North Lanzo peridotite body (NW Italy): lithospheric mantle percolated by MORB and alkaline melts. Period Mineral 76: 199-221. 
Citation: Bhattacharyya K (2015) Rift that will Host Important Deposits of Hydrocarbons: A Review of the Petrologic Constraints Recorded by the Mantle Peridotites from Ophiolite Massifs. Global J Technol Optim 6: 183. doi:10.4172/2229-8711.1000183

51. Piccardo GB, Vannucci R, Guarnieri L (2009) Evolution of the lithospheric mantle in an extensional setting: insights from ophiolitic peridotites. Lithosphere 1: $81-87$

52. Piccardo GB, Ranalli G, Guarnieri L (2010) Seismogenic Shear Zones in the Lithospheric Mantle: Ultramafic Pseudotachylytes in the Lanzo Peridotite (Western Alps, NW Italy). J Petrol 51: 81-100.

53. Piccardo GB, Guarnieri L (2010) Alpine peridotites from the Ligurian Tethys: an updated critical review. Int Geol Rev 52: 1138-1159.

54. Piccardo GB, Guarnieri L (2011) Gabbro-norite cumulates from strongly depleted MORB melts in the Alpine-Apennine ophiolites. Lithos 124: 210-214.

55. Kelemen PB, Dick HJB, Quick JE (1992) Formation of harzburgite by pervasive melt/rock reaction in the upper mantle. Nature 358: 635-641.

56. Kelemen PB, Whitehead JA, Aharonov E, Jordahl KA (1995) Experiments on flow focusing in soluble porous media, with applications to melt extraction from the mantle. J Geophys Res 100: 475-496.

57. Kelemen PB, Shimizu N, Salters VJM (1995) Extraction of mid-ocean-ridge basalt from the upwelling mantle by focused flow of melt in dunite channels. Nature 375: 747-753.

58. Borghini G, Fumagalli P, Rampone E (2010) The stability of Plagioclase in the Upper Mantle: subsolidus experiments on fertile and depleted Iherzolite. $J$ Petrol 51: 229-254.

59. Green DH, Hibberson WO, Kovacs I, Rosenthal A (2011) Water and its influence on the lithosphere-asthenosphere boundary. Nature 472: 504.

60. Anderson D L (1995) Lithosphere, asthenosphere, and perisphere. Review of Geophysics 33: 125-149.

61. Fischer KM, Ford HA, Abt DL, Rychert CA (2010) The lithosphereasthenosphere boundary. Annu Rev Earth Planet Sci 38: 551-575.

62. Panza G, Doglioni C, Levshin A (2010) Asymmetric ocean basins. Geology 38: $59-62$.

63. Doglioni C, Ismail-Zadeh A, Panza G, Riguzzi F (2011) Lithosphereasthenosphere viscosity contrast and decoupling. Phys. Earth Planet Inter 189 $1-8$

64. Panza G, Pontevivo A, Chimera G, Raykova R, Aoudia A (2003) The lithosphere- asthenosphere: Italy and surroundings. Episodes 26: 169-174

65. Brandmayr E (2010) The lith-osphere in Italy: structure and seismicity. J Virtua Explor Electronic Edition 1.

66. Rampone E, Romairone A, Hofmann AW (2004) Contrasting bulk and mineral chemistry in depleted peridotites: evidence for reactive porous flow. Earth Planet Sci Lett 218: 491-506.

67. Mohajeri A, Finzi Y, Muhlhaus H, Rosembaum G (2013) Melt and shear interactions in the lithosphere: theory and numerical analysis of pure-shear extension. J Geophys Res Solid Earth 118: 2488-2499.

68. Buck WR (2006) The role of magma in the development of the Afro-Arabian Rift System.

69. Corti G (2012) Evolution and characteristics of continental rifting: analog modeling- inspired view and comparison with examples from the East African Rift System. Tectonophysics 522-523: 1-33.

70. Ebinger C (2005) Continental breakup: the East African perspective. Astron Geophys 46: 216- 221.

71. Dijkstra AH, Barth MG, Drury MR, Mason PRD, Vissers RLM (2003) Diffuse porous melt flow and melt-rock reaction in the mantle lithosphere at a slow spreading ridge: a structural petrology and LA-ICP-MS study of the Othris Peridotite Massif (Greece). Geochem Geophys Geosyst.

72. Montanini A, Tribuzio R, Anczkiewicz R (2006) Exhumation history of a garnet pyroxe- nite bearing mantle section from a continent-ocean transition (Northern Apennine ophiolites, Italy). J Petrol 47: 1943-1971.

73. Müntener O, Hermann J (2001) The role of lower crust and continental upper mantle during formation of non-volcanic passive margins: evidence from the Alps. Geol Soc Lond Spec Publ 187: 267-288.

74. Tribuzio R, Thirwall MF, Vannucci R (2004) Origin of the gabbroperidotite association from the Northern Apennine ophiolites (Italy). J Petrol 45: 1109 2277.
75. Borghini G, Rampone E, Crispini L, De Ferrari R, Godard M (2007) Origin and emplace-ment of ultramafic-mafic intrusions in the Erro-Tobbio mantle peridotite (Ligurian Alps, Italy). Lithos 94: 210-229.

76. Rampone E, Romairone A, Abouchami W, Piccardo GB, Hofmann AW (2005) Chronology, petrology and isotope geochemistry of the Erro-Tobbio peridotites (Ligurian Alps, Italy): records of Late Palaeozoic lithospheric extension. J Petrol 46: 799-827.

77. Piccardo GB, Müntener O, Zanetti A, Pettke T (2004) Ophiolitic peridotites of the Alpine-Appenine system: mantle processes and geodynamic relevance. In Geol Rev 46: 1119-1159.

78. Rampone E, Hofmann AW, Piccardo GB, Vannucci R, Bottazzi P, et al. (1995) Petrology, mineral and isotope geochemistry of the External Liguride peridotites (Northern Apennine, Italy). J Petrol 36: 81-105.

79. Rampone E, Piccardo GB, Hofmann AW (2008) Multi-stage melt-rock interaction in the Mt. Maggiore (Corsica, France) ophiolitic peridotite: microstructural and geochemical evidence. Contrib. Mineral Petrol 156: 453-475.

80. Rampone E, Piccardo GB, Vannucci R, Bottazzi P, Ottolini L (1993) Subsolidus reactions monitored by trace element partitioning: the spinel- to plagioclasefacies transition in the mantle peridotites. Contrib Mineral Petrol 115: 1-17.

81. Rampone E, Hofmann AW, Raczek I (1998) Isotopic contrasts within the Internal Liguride ophiolite (N. Italy): the lack of a genetic mantle-crust link. Earth Planet Sci Lett 163: 175-189.

82. Rampone E, Hofmann AW, Raczek I (2009) Isotopic equilibrium between mantle peridotite and melt: Evidence from the Corsica ophiolite. Earth Planet Sci Lett 288: 601-610.

83. Kaczmarek MA, Müntener O, Rubatto D (2008) Trace element chemistry and $\mathrm{U}-\mathrm{Pb}$ dating of zircons in oceanic gabbros and their relationship with whole rock composition (Lanzo, Italian Alps). Contrib Mineral Petrol 155: 295-312.

84. Li X H, Faure M, Linn W, Manatschal G (2013) New isotopic constraints on age and magma genesis of an embryonic oceanic crust: the Chenaillet Ophiolite in the Western Alps. Lithos 160-161: 283-291.

85. Bill M, O'Dogherty L, Guex J, Baumgartner PO, Masson H (2001) Radiolarite ages in Alpine-Mediterranean ophiolites: constraints on the oceanic spreading and the Tethys-Atlantic connection. Geol Soc Am Bull 113: 129-143.

86. von der Handt, A, Hellebrand, E, Laukert G, Schmidt R, Snow JE (2011) Melt stagnation in the upper mantle and lower crust at slow- to ultraslow-spreading ridges. American Geophysical Union Fall Meeting 21: 2489.

87. Dick HJB (1989) Abyssal peridotites, very slow spreading ridges and ocean ridge magmatism.

88. Seyler M, Bonatti E (1997) Regional-scale melt-rock interaction in Iherzolitic mantle in the Romanche fracture zone (Atlantic Ocean). Earth Planet Sci Lett 146: $273-287$.

89. Tartarotti $P$, Susini $S$, Nimis $P$, Ottolini $L$ (2002) Melt migration in the upper mantle along the Romanche Fracture Zone (Equatorial Atlantic). Lithos 63 125-149.

90. von der Handt A, Snow JE, Hellebrand E, Dick HJB, Michael P (2003) Shallow mantle melt stagnation under Gakkel Ridge. Geophys Res Abstr 5: 11703.

91. von der Handt A, Snow JE, Hellebrand E (2006) A quantitative assessment of melt origin versus subsolidus formation of plagioclase in Gakkel Ridge peridotites. Ofioliti 31: 248-249.

92. Hellebrand E, Snow JE, Dick HJB, von der Handt A (2006) Inherited depletion in the oceanic mantle: peridotite composition and distribution along Gakke Ridge. Ofioliti 31: 225- 249

93. Handt AV (2008) Deciphering Petrological Signatures of Reactive Melt Stagnation and Cooling in the Oceanic Mantle underneath Ultraslow-Spreading Ridges. Johannes Gutenberg University, Mainz, Germany.

94. Dick HJB, Lissenberg CJ, Warren JM (2009) Mantle melting, melt transport and delivery beneath a slow-spreading ridge: the Paleo-MAR from $23^{\circ} 15^{\prime} \mathrm{N}$ to $23^{\circ} 45^{\prime}$ N. J Petrol 51: 425-467.

95. Warren JM, Shimizu N (2010) Cryptic variations in abyssal peridotite compositions: evidence for shallow-level melt infiltration in the oceanic lithosphere. J Petrology 51: 395-423.

96. Seyler M, Brunelli D, Toplis MJ, Mével C (2011) Multiscale chemical 
Citation: Bhattacharyya K (2015) Rift that will Host Important Deposits of Hydrocarbons: A Review of the Petrologic Constraints Recorded by the Mantle Peridotites from Ophiolite Massifs. Global J Technol Optim 6: 183. doi:10.4172/2229-8711.1000183

Page 9 of 9

heterogeneities be-neath the eastern Southwest Indian Ridge $\left(52^{\circ} \mathrm{E}-68^{\circ} \mathrm{E}\right)$ : trace element compositions of along-axis dredged peridotites. Geochem Geophys Geosyst 12: Q0AC15.

97. Paganelli E, Brunelli D, Seyler M, Bonatti E, Cipriani A, et al. (2011) Deep versus shallow melt stagnation in an ultra-slow/ultra-cold ridge segment: the Andrew Bain southern RTI (SWIR). American Geophysical Union, America.

98. Snow J, Hellebrand E, von der Handt A, Nauret F, Gao Y, et al. (2011) Oblique nonvolcanic seafloor spreading in Lena Trough, Arctic Ocean. Geochem Geophys Geosyst 12: Q10009.

99. Seitz HM, Altherr R, Ludwig T (1999) Partitioning of transition elements between orthopyroxene and clinopyroxene in peridotitic and websteritic xenoliths: new empirical geothermometers. Geochim Cosmochim Acta 63: 3967-3982.

100. Hodges FN, Papike JJ (1976) DSDP Site 334: magmatic cumulates from oceanic layer 3. J Geophys Res 81: 4135-4151.

101. Ross K, Elthon D (1993) Cumulates from strongly depleted mid-ocean-ridge basalt. Nature 365: 826-829.

102. Johnson KTM, Dick HJB, Shimizu N (1990) Melting in the oceanic upper mantle an ion microprobe study of diopsides in abyssal peridotites. J Geophys Res Solid Earth Planets 95: 2661-2678. 